\title{
KONTRIBUSI PENDIDIKAN ENTREPRENEURSHIP: SUATU UPAYA KONSTRUKTIF MENUMBUHKAN JIWA WIRAUSAHA PADA MAHASISWA
}

\author{
Dainuri \\ Sekolah Tinggi Agama Islam Al Hikmah Tuban \\ dainurias@yahoo.com
}

\begin{abstract}
Abstact
In a developing country, the role of entrepreneurs cannot be ignored especially in carrying out development. A nation will develop faster if it has entrepreneurs who can create and innovate optimally, which is to realize new ideas into real activities in each of their businesses. Indonesia as a developing country is working hard to improve the lives of its people. One important role in improving the standard of living of its people is through education. Entrepreneurship education is one form of application of the world's care for education to the progress of the nation. In entrepreneurship education it is shown, among others, the value and form of work to achieve success. Entrepreneurship education is a help to teach Indonesian people so that they have a dynamic and creative personal power in accordance with the personality of the Indonesian people based on Pancasila. fostering the spirit of entrepreneurship is one of the important things to be job opportunities, income and welfare for everyone/individual.
\end{abstract}

Keywords: Education, Entrepreneurship Education, Student

\section{Pendahuluan}

Sebagaimana diketahui salah satu tujuan kebijaksanaan pembangunan nasional adalah meningkatkan produksi yang disertai dengan penciptaan lapangan kerja baru yang seluas-luasnya dan penyebaran pendapatan yang lebih merata. Berdasarkan uraian di atas, maka sudah sewajarnya para lulusan perguruan tinggi/sekolah diajak untuk memahami secara realistis keadaan sekarang ini dalam hubungannya dengan masalah kesempatan kerja. Juga perlu disadari bahwa tanggung jawab mereka tergantung sepenuhnya pada diri mereka.

Pembangunan pendidikan nasional ditujukan untuk mewujudkan cita-cita kemerdekaan bangsa Indonesia khususnya dalam upaya mencerdaskan kehidupan bangsa sehingga akan menjadi bangsa yang beradab dan dapat bersaing di dunia Internasional. Salah satu upaya mewujudkan tujuan pendidikan itu terutama di 
perguruan tinggi/sekolah telah dikembangkan dan dilaksanakan pelajaran kewirausahaan sebagai mata pelajaran. sejalan dengan pendapat Ciputra yang menyatakan bahwa Pendidikan entrepreneurship akan mampu menghasilkan dampak nasional yang besar bila kita berhasil mendidik seluruh bangku sekolah kita dan mampu menghasilkan empat juta entrepreneur baru dari lulusan lembaga pendidikan Indonesia selama 25 tahun mendatang.

Perguruan Tinggi pada dasarnya adalah wadah pencetak sarjana yang siap menyumbangkan pemikirannya dalam kemajuan di negara Indonesia, tetapi kenyataannya hanya mampu mencetak "pengangguran" yang jumlahnya semakin bertambah. Jumlah "pengangguran" ini dari tahun ke tahun mengalami peningkatan, sedangkan jumlah lapangan pekerjaan yang tersedia tidak mampu menyerap jumlah sarjana yang selalu bertambah tiap tahunnya ini. Minimnya peran serta Perguruan Tinggi untuk menumbuhkembangkan jiwa kewirausahaan inilah yang mematikan jiwa kewirausahaan pada para calon sarjana. Pendidikan kewirausahaan sebenarnya sudah cukup lama diperhatikan. Sejumlah perguruan tinggi telah membentuk dan menerapkan kuliah kewirausahaan sejak beberapa tahun silam. Sejumlah sekolah menengah juga melakukan hal yang sama. Tetapi, kelahiran wirausaha di Indonesia dirasakan masih jauh dari harapan. Menurut Kemendiknas (2010) pendidikan kewirausahaan di Indonesia masih kurang memperoleh perhatian yang cukup memadai, baik oleh dunia pendidikan maupun masyarakat sendiri. Strategi pembelajaran kewirausahaan di Indonesia belum bisa memungkinkan lahirnya wirausaha baru sesuai harapan. Penyebabnya, karena strategi pembelajaran Indonesia masih sangat condong pada pembelajaran yang berpusat pada guru. Pembelajaran yang berpusat pada guru adalah sistem pembelajaran yang menjadikan guru sebagai pusat dan sumber utama yang memberikan ide-ide.

Kewirausahaan merupakan solusi bagi suatu negara, bukan hanya untuk mengatasi masalah "pengangguran" saja tetapi sampai kepada meningkatkan pertumbuhan ekonomi di negara. Semakin banyak jumlah wirausaha di suatu negara, mengindikasikan semakin maju, semakin makmur dan semakin negara tersebut. Semakin banyak jumlah wirausaha, akan mampu meningkatkan standar hidup dan kualitas hidup di negara tersebut. Otomatis, permasalahan di negara 
Indonesia yang berkutat pada jumlah pengangguran yang semakin tinggi setiap tahunnya yang menambah daftar tingginya tingkat kemiskinan yang mempengaruhi tingginya angka kejahatan serta tingginya tingkat kerusakan lingkungan, dapat diatasi. Dimulai dari Perguruan Tinggi, dimulai dari dunia pendidikanlah, jiwa kewirausahaan ditumbuhkan pada diri calon sarjana ini yang tentunya akan mampu mencetak wirausaha-wirausaha sejati.

Sebagaimana kita pahami bersama makna dari entrepreneurship sendiri menurut ahli pendidik entrepreneurship, adalah jiwa yang memiliki motivasi tinggi, toleransi terhadap resiko yang cukup tinggi, selalu ingin berprestasi, pantang menyerah, mampu menciptakan peluang, kreatif, serta memiliki kepercayaan diri dan memiliki jiwa kepemimpinan yang tinggi. Karakter entrepreneurship tersebut sangat cocok sebagai modal untuk dapat sukses di era global seperti saat ini. Mengembangkan karakter entrepreneurship, bukan berarti menciptakan pedagang atau wira usaha, namun terlebih dari itu, jiwa kewirausahaan (entrepreneurship) ini dipandang sebagai satu ciri karakter yang memiliki kekuatan pribadi dalam menghadapi tantangan dunia. Seorang dengan karakter entrepreneurship ini, diharapkan mampu menjadi penggerak kemajuan bangsa.

\section{Pemahaman Pendidikan Enterpreneurship}

Pendidikan enterpreneurship adalah mengembangkan konsep pendidikan holistik, yakni mendidik manusia seutuhnya. Meliputi 4H (Head, Hand, Health, dan Heart). Selaras dengan empat pilar pendidikan rumusan UNESCO, yaitu: (1) Learning to know (2) Learning to do (3) learning to be (4) Learning to live together. ${ }^{1}$ Menurut W.S. Wingkle S.J Pendidikan enterpreneurship termasuk belajar estetis. Belajar estetis adalah salah satu dari empat bentuk belajar, yaitu belajar teoritis, belajar teknis, belajar bermasyarakat. ${ }^{2}$ Sedangkan menurut Hendro bahwa "mata kuliah kewirausahaan (pendidikan enterpreneurship) merupakan suatu konsep pembelajaran yang terpadu yang dirancang khusus bagi mahasiswa untuk mempelajari konsep, taktik, strategi, dan pengetahuan mengenai cara

\footnotetext{
${ }^{1}$ Fadlullah, Pendidikan Enterpreneurship Berbasis Pendidikan Islam dan Kearifan Lokal (Jakarta: Diadid Media Press, 2011), 119

${ }^{2}$ W.S. Wingkle S.J, Psikologi Pengajaran (Yogyakarta: Media Abadi, 2009), 82
} 
memulai usaha serta mengubah pola pikir dan paradigma mengenai kewirausahaan". 3 Pendidikan enterpreunership merupakan pendidikan yang di tujukan untuk menumbuhkan keahlian khusus. Hal ini mengacu pada pandangan Peter F. Drucker yang di kutip oleh Kasmir bahwa berwirausaha merupakan suatu kegiatan yang membutuhkan kreatifitas dan inovasi baru, sehingga mampu untuk menciptakan sesuatu yang belum ada sebelumnya dan kewirausahaan merupakan suatu kemampuan dalam hal menciptakan kegiatan usaha. ${ }^{4}$ Kreatifitas itu sendiri bukanlah suatu karakter yang dapat di bentuk dengan mudah, yaitu sebagaimana

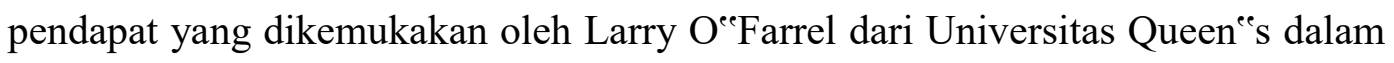
konferensi internasional (APEID) the Asia Pasific Programme of Educational Innovation for Development di Biro Regional Pendidikan Asia Pasifik UNESCO di Bangkok, Thailand, Bahwa kemampuan kreatif ada dalam diri kita dalam berbagai tingkat. Masalahnya adalah bagaimana kita dapat menggali hingga kemampuan itu muncul dan bermanfaat bagi kita. ${ }^{5}$

Pendidikan enterpreneurship merupakan salah satu bentuk aplikasi kepedulian dunia pendidikan terhadap kemajuan bangsanya. Di dalam Pendidikan enterpreneurship diperlihatkan di antaranya adalah nilai dan bentuk kerja untuk mencapai kesuksesan. Menurut Suparman Suhamidjaja bahwa:" Pendidikan enterpreneurship adalah pendidikan yang bertujuan untuk menempa bangsa Indonesia sesuai dengan kepribadian Indonesia yang berdasarkan Pancasila". Dalam arti yang lebih luas bahwa Pendidikan enterpreneurship adalah pertolongan untuk membelajarkan manusia Indonesia sehingga mereka memiliki kekuatan pribadi yang dinamis dan kreatif sesuai dengan kepribadian bangsa Indonesia yang berdasarkan pancasila.

Pendidikan enterpreneurship adalah pendidikan yang berorientasi pada skill. Maka kemunculannya secara spesifik baru sangat terasa dalam dunia pendidikan di Indonesia semenjak diterapkannya kurikulum 2013. Dalam kurikulum 2013, kurikulum 2013 diterapkan dan ditujukan agar guru memperoleh ruang yang lebih leluasa untuk mengembangkan potensi siswa secara seimbang

\footnotetext{
${ }^{3}$ Hendro, Dasar- Dasar Kewirausahaan, (Jakarta: Erlangga, 2011), 1.

${ }^{4}$ Kasmir, Kewirausahaan (Jakarta: PT Raja Grafindo Persada, 2011), 21

${ }^{5}$ Kabar Pendidikan, konferensi internasional UNESCO-APEID ke-15, "Menumbuhkan Inspirasi dalam Pendidikan : Kreatifitas dan Kewirausahaan”, Edisi 5 Februari 2012. 2.
} 
dalam tiga aspek, yaitu aspek kognitif, psikomotorik dan afektif. ${ }^{6}$ yang mana dijadikan acuan dalam taksonomi bloom. Sasaran pembelajarannya telah memenuhi tiga ranah yang sesuai dengan standar kompetensi kelulusan yang seharusnya ada pada diri peserta didik.

Jika memang demikian, maka munculnya pendidikan enterpreneurship di Indonesia adalah reaksi pemerintah RI untuk menjadi Negara yang mandiri dalam hal ekonomi, sehingga berupaya untuk meningkatan wirausahawan guna memenuhi rasio ideal Internasional dengan cara memulai pendidikan Enterpreneurship atau kewirausahaan.

\section{Latar Belakang Munculnya Pendidikan Enterpreneurship}

Pendidikan Enterpreneurship sudah dikenal orang dalam sejarah ilmu ekonomi sebagai ilmu pengetahuan sejak tahun $1755 .^{7}$ Landasan teoritik pendidikan enterpreneurship tidak lepas dari diskusi klasik para ahli tentang natur versur nurtur. Apakah enterpreneurship itu dilahirkan atau diajarkan? ${ }^{8}$ Di zaman dahulu, cikal bakal ilmu pengetahuan kewirausahaan, ialah selling skill is the core of enterpreneurial skill dan menjadi sebuah ilmu untuk menjadi kaya dan sukses yang sudah ada sejak zaman dahulu. ${ }^{9}$ Faktor utama yang melatarbelakangi munculnya pendidikan enterpreneurship itu sendiri adalah semakin pesatnya angka lulusan yang menjadi pengangguran sehingga bermuara terhadap daya saing ekonomi yang semakin menurun. Enterpreneurship yang dipraktekkan di dalam sebuah organisasi yang mapan, seperti sekolah disebut corporate enterpreneurship atau intrapreneurship yang mulai diperkenalkan pada tahun $1976 .{ }^{10}$ Di Indonesia yang mayoritas masyarakatnya lebih menyukai pekerjaan yang menjanjikan dan syarat akan kenyamanan, padahal kenyamanan yang berkala akan memunculkan pribadi yang lemah dan kurang mampu bersaing. Rendahnya wirausahawan di Indonesia jika dibandingkan dengan beberapa Negara bisa dikatakan tertinggal jauh. Rasio kewirausahaan di

${ }^{6}$ Mulyoto, Strategi Pembelajaran di Era Kurikulm 2013 (Jakarta: Prestasi Pustaka Raya, 2013), 12.

${ }^{7}$ J. Wijardi, Enterpreneur dan Enterpreneurship (Jakarta: Kencana, 2008), 1.

${ }^{8}$ Fadlullah, Pendidikan Enterpreneurship Berbasis Pendidikan Islam dan Kearifan Lokal, 122.

${ }^{9}$ Hendro, Dasar- Dasar Kewirausahaan, (Jakarta: Erlangga, 2011), 25.

${ }^{10}$ Fadlullah, Pendidikan Enterpreneurship Berbasis Pendidikan Islam dan Kearifan Lokal, 276. 
Indonesia adalah 1:83, sedangkan. di Filipina adalah 1:66, Jepang 1:25, dan Korea kurang dari dua puluh. Berdasarkan rasio secara Internasional, rasio unit usaha ideal adalah 1:20. ${ }^{11}$

Dalam hal pendidikan kewirausahaan (enterpreneurship), Indonesia tertinggal jauh dibanding dengan luar negri, bakan dibeberapa negara pendidikan tersebut bahkan telah dilakukan puluhan tahun yang lalu. Misalnya, di negara-negara Eropa atau Amerika Utara pendidikan entrepreneurship sudah dimulai sejak tahun 1970-an. Bahkan di Amerika Serikat lebih dari 500 sekolah sudah mengajarkan mata kuliah kewirausahaan era tahun 1980-an. Sementara itu di Indonesia pendidikan entrepreneurship baru mulai dibicarakan era tahun 1980-an dan digalakkan tahun 1990-an. Hasilnya kita patut bersyukur bahwa dewasa ini sudah berdiri beberapa sekolah yang memang berorientasi untuk menjadikan mahasiswanya sebagai calon pengusaha unggul setelah pendidikan. meskipun masih terdengar sayup gaung lahirnya wirausaha-wirausaha baru, minimal kita sudah memulainya. ${ }^{12}$ Dahulu, prestasi dan pendidikan saja sudah cukup untuk menjadi bekal mencari pekerjaan dan bertahan hidup. Namun, dewasa ini apakah prestasi dan pendidikan itu masih cukup? belum tentu! Oleh sebab itu, ada banyak tujuan pendidikan enterpreneurship yang bisa dimanfaatkan oleh para lulusan perguruan tinggi dan dunia pendidikan untuk mewujudkan impiannya. ${ }^{13}$ Tranformasi pengetahuan kewirausahaan telah berkembang pada akhir-akhir ini. Demikian pula di negara kita pengetahuan kewirausahaan diajarakan di sekolah dasar, sekolah menengah, sekolah tinggi dan di berbagai kursus bisnis. ${ }^{14}$

\section{Tujuan Pendidikan Enterpreneurship}

Secara umum, peran penting pendidikan adalah untuk menghasilkan tenaga-tenaga profesional yang memilki kapasitas dan kapabilitas kemampuan berwirausaha yang menjadi salah satu pilar utama aktivitas perekonomian nasional, membagun kemandirian bangsa, dan meningkatkan daya saing

\footnotetext{
11 Yuyus Suryana dan Kartib Bayu, Kewirausahaan: Pendekatan Karakteristik Wirausahawan Sukses (Jakarta: Kencana, 2011), 15.

${ }^{12}$ Kasmir, Kewirausahaan, (Jakarta: Rajawalipres, 2009), 4.

${ }^{13}$ Hendro, Dasar-Dasar Kewirausahaan, (Jakarta: Erlangga, 2011), 7.

${ }^{14}$ Buchari Alma, Kewirausahaan (Bandung: Alfabeta, 2016), 6.
} 
nasional. ${ }^{15}$ Maka untuk menjalankan peran pentingnya pendidikan, pendidikan enterpreneurship atau kewirausahaan telah mendapatkan perhatian pada lembaga-lembaga pendidikan tinggi di Indonesia. ${ }^{16}$ Pendidikan dan pelatihan kewirausahaan bertumbuh pesat di Eropa dan Amerika Serikat baik ditingkat kursus-kursus ataupun di Universitas.

Berikut penulis telah merangkum dari berbagai literatur. Secara umum, tujuantujuan pendidikan entrepreneurship adalah:

\section{a. Membentuk jiwa kemandirian}

Menurut Hendro dalam karyanya Dasar-dasar Kewirausahaan bahwa, "pendidikan enterpreneurship atau kewirausahaan dalam dunia pendidikan, salah satu tujuan dan manfaatnya adalah membudayakan sikap unggul, prilaku positif dan kreatif. Juga menjadi bekal ilmu untuk mencari nafkah, bertahan hidup dan berkembang". ${ }^{17}$ Belajar dan berlatih wirausaha atau enterpreneurship adalah solusi terbaik guna menghadapi masa depan, mengingat persaingan berusaha yang semakin ketat, sementara lahan pertanian, perkebunan juga semakin sempit, maka akan sangat bijak sana jika sejak dini, para santri, pelajar dan pemuda telah mempersiapkan diri, belajar tentang berbagai hal berkaitan dengan kewirausahaan atau enterpreneurship. ${ }^{18}$ Kemandirian dan kesuksesan itu hanya milik orang-orang yang niat yang kuat dan berani mencoba, mengambil resiko, tidak mudah menyerah dan putus asa. Orang yang bermental mandiri tidak akan menganggap kesulitan sebagai hambatan, melainkan sebagai tantangan dan peluang. Kalau tidak berani mencoba, padahal ada peluang, berarti telah gagal. Tidak ada kata gagal dalam berwirausaha atau enterpreneurship. bila mengalami kegagalan, anggap itu sebagai pengalaman, pelajaran dan sebuah informasi berharga untuk menuju sukses. Demikian pendapat menurut Abdullah Gymnastiar yang dikutip oleh Sudradjat Rasyid dan Muhammad Nasri. Sedangkan jiwa kemandirian menurut Rofiq A., R.B. Widodo, Icep Fadlil Yani, Romdin A., Rudhy Suharto, dan Mahya Ramdhani "adalah hasrat untuk mengerjakan segala sesuatu bagi diri sendiri yang

15 Yoyon Bahtiar Irianto, Kebijakan Pembaharuan Pendidikan: Konsep, Teori, dan Model (Jakarta: PT. Rajagrafindo Persajaq, 2012), 6.

${ }^{16}$ Wijaya, Enterpreneurship Bagaimana Menciptakannya, v.

${ }^{17}$ Hendro, Dasar-dasar Kewirausahaan, 8.

${ }^{18}$ Rasyid dan Nasri, Kewirausahaan Santri, 26. 
diwujudkan dalam aspek kreativitas dan kemapuan mencipta"19

\section{b. Mengurangi jumlah pengangguran}

Pendidikan enterpreneurship bertujuan untuk mengurangi pengangguran. Ilmu dalam pendidikan enterpreneurship bukan merupakan ilmu ajaib yang mendatangkan uang dalam waktu sekejap, melainkan sebuah ilmu, seni, dan keterampilan untuk mengelola semua keterbatasan sumber daya, informasi, dan dana guna, mempertahankan hidup, mencari nafkah, atau meraih posisi puncak dalam berkarir.

Setiap tahun lulusan perguruan tinggi dan sederajat berjumlah jutaan. Hampir sebagian besar dari jumlah itu berorientasi mencari kerja. Itupun belum ditambah dengan lulusan tahun sebelumnya yang belum mendapatkan pekerjaan. bergabung dengannya bisa menjadi 20\% (satu partner dan satu karyawan)., jumlah pencari kerja angkatan tahun tersebut otomatis berkurang $30 \%$. Seandainya sebagian kecil saja lulusan yang berfikir sama, maka wirausaha bisa menjadi cara dan alternatif untuk mengurangi pengangguran yang sekarang ini jumlahnya cukup tinggi. Pendidikan Enterpreneurship akan menciptakan dampak yang

strategis bagi kemajuan bangsa Indonesia di masa depan. "Masa depan adalah masa dimana orang berfikir out of the box". ${ }^{20}$ Maksudnya bahwa orang-orang tidak hanya terpacu pada suatu cara atau suatu tempat saja, melainkan juga berani mencoba untuk mengambil alternatif yang baru dengan cara menyatukan berbagai macam pengetahuan. Dengan kata lain bahwa manusia harus lebih kreatif dalam menghadapi berbagai persoalan, sehingga dapat menyusutkan angka pengangguran.

Dapat disimpulkan bahwa enterpreneurship atau kewirausahaan lebih dari sekedar mengumpulkan kekayaan atau mewujutkan cita-cita. Akan tetapi enterpreneurship bisa di dapat dengan cara belajar. Oleh karena itu, pendidikan kewirausahaan (enterpreneurship) jelas sangat diperlukan. lebih-lebih untuk

19 Rofiq A., R.B. Widodo, dkk., Pemberdayaan Pesantren Menuju Kemandirian dan Profesionalisme Santri dengan Metode Dauroh Kebudayaan (Yogyakarta: Pustaka Pesantren, 2005), 90.

20 Barnawi dan Mohammad Arifin, School Preneurship: Membangkitkan Jiwa dan Sikap Kewirausahaan Siswa (Jogjakarta: Ar-Ruzz Media, 2012), 17. 
mengatasi pengangguran dan kemiskinan yang absolut dan permanen. Dan ketika seseorang mampu mempekerjakan orang-orang yang lebih pintar darinya, maka seseoran itu telah membuktikan bahwa dirinya lebih pintar dari pada mereka

\section{c. Membudayakan Semangat Wirausaha di Masyarakat}

Wirausahawan dapat dikategorikan sebagai orang-orang yang memiliki jiwa tangguh, kompetitif, dan pandai mencari peluang. Semangat wirausaha yang tidak pernah padam ini sangat baik jika mampu ditularkan ke masyarakat sebagai sebuah tujuan kewirausahaan yang selanjutnya. Tujuan kewirausahaan membudayakan semangat wirausaha di masyarakat dapat diwujudkan dengan cara yang sangat sederhana, yaitu dengan bersikap seperti apa adanya seorang entrepreneur. Sikap tersebut tentunya akan menginspirasi dan membuat masyarakat tergerak untuk mencoba berwirausaha. Sikap tangguh dan tidak mudah menyerah juga sebaiknya diperlihatkan supaya tujuan kewirausahaan ini dapat membangun semangat orang-orang muda di masyarakat supaya mau bekerja keras untuk mendapatkan keberhasilan. ${ }^{21}$

\section{Upaya Perguruan Tinggi dalam Mendorong Wirausahawan}

Upaya peningkatan gema kewirausahaan di perguruan tinggi, sangat terkait dengan elemen yang berperan di dalamnya, tenaga pendidik misalnya, yang paling dekat dan konsen menangani kewirausahaan di perguruan tinggi. Bukti nyata kebijakan pemerintah ini adalah dengan memasukkan mata kuliah Kewirausahaan dalam kurikulum pembelajaran, khususnya di tingkat perguruan tinggi, dimana tingkatan ini merupakan tahap akhir sebelum para mahasiswa memasuki dunia kerja yang sebenarnya. Banyaknya pengangguran serta kurangnya minat berwirausaha menjadi autokritik terhadap peran dari perguruan tinggi. perguruan tinggi memiliki peran yang besar dan memiliki peluang untuk menanamkan sikap mental kewirausahaan sehingga lulusannya tidak hanya ahli pada suatu bidang akademi namun juga mampu melahirkan wirausahawanwirausahawan baru yang siap menjadi pahlawan ekonomi.

Ada beberapa langkah yang dapat dilakukan dalam menciptakan

\footnotetext{
${ }^{21}$ Endang Mulyani, Model Pendidikan Kewirausahaan di Pendidikan Dasar dan Menengah, 2.
} 
wirausahawan di Perguruan Tinggi, antara lain :

a. Memasukkan kurikulum kewirausahaan dalam kurikulum pendidikan. Dengan memasukkan kurikulum kewirausahaan, maka diharapkan Perguruan Tinggi sebagai lembaga pendidikan yang berorientasi pada menghasilkan sumber daya manusia yang (wirausahawan).

b. Mendirikan laboratorium kewirausahaan Dengan adanya laboratorium kewirausahaan, mahasiswa mampu mempraktikkan langsung ilmu yang diterima. Jadi ada penggabungan antara teori dan praktik. Kurikulum yang ada saat ini pada dasarnya hanya menekankan pada salah satunya saja. Laboratorium kewirausahaan tentunya akan mampu memberikan gambaran yang jelas tentang praktik kewirausahaan. Pengetahuan mahasiswa tentang ekonomi, kewirausahaan dan bisnis baru sebatas pada teori. Sikap pesimistis mahasiswa terhadap ketiga hal tersebut, bahwa hal tersebut tidak dapat dipraktikkan secara holistik dapat terhapuskan dengan adanya laboratorium ini.

c. Mengadakan pelatihan-pelatihan kewirausahaan. Dengan mengadakan pelatihan kewirausahaan di Perguruan Tinggi yang tidak hanya ditujukan ke mahasiswa tetapi juga ke dosennya.

d. Memberikan dukungan bagi wirausaha-wirausaha muda dengan memberikan bantuan dana lunak. Saat ini perhatian pemerintah dan Perguruan Tinggi terhadap mahasiswa yang akan membuka usaha dan yang sedang membuka usaha masih sangat minim. Padahal dengan memberikan perhatian yang besar terhadap para wirausaha muda ini, seperti bantuan dana seperti pinjaman lunak akan mampu memotivasi mahasiswa untuk membuka dan mengembangkan usahanya.

e. Kewirausahaan Nyata. KKN yang bertujuan menjadikan mahasiswa dekat dengan masyarakat dnegan melakukan pengabdian langsung ke masyarakat ternyata faktanya tidaknya seperti yang diharapkan. Hanya sebagian kecil mahasiswa yang mampu aktif terlibat langsung ke masyarakat dan mengaplikasikan kelimuannya secara optimal, sedangkan sebagian lainnya pasif. Oleh sebab itu merubah KKN menjadi Kewirausahaan Nyata sepertinya merupakan solusi yang tepat, dimana 
mahasiswa telah memiliki program yang jelas sebelum terjun kelapangan dan tanpa perlu "stay" di masyarakat. Disini mahasiswa sebagai mentor dan juga ikut terlibat dalam kegiatan kewirausahaan di masyarakat, dan posisi dosen sebagai mentor bagi mahasiswa.

\section{Menumbuhkan Jiwa Kewirausahaan Mahasiswa}

Perguruan Tinggi sebagai lembaga pendidikan seharusnya memiliki peranan yang besar dalam menumbuhkan jiwa kewirausahaan pada mahasiswanya dengan memberikan dorongan-dorongan yang nyata demi terciptanya sarjana-sarjana yang berjiwa kewirausahaan.

Langkah awal yang dapat dilakukan apabila berminat terjun ke dunia usaha adalah menumbuhkan jiwa kewirausahaan pada diri mahasiswa. Banyak cara yang dapat dilakukan, misalnya melalui :

a. Pendidikan formal. Kini berbagai lembaga pendidikan, baik menengah maupun tinggi menyajikan berbagai program atau paling tidak mata kuliah kewirausahaan.

b. Seminar kewirausahaan. Berbagai seminar kewirausahaan seringkali diselenggarakan dengan mengundang pakar dan praktisi kewirausahaan, sehingga melalui media ini akan membangun jiwa kewirausahaan di kalangan mahasiswa.

c. Pelatihan. Berbagai simulasi usaha biasanya diberikan melalui pelatihan, baik yang dilakukan dalam ruangan (indoor) maupun di luar ruangan (outdoor). Melalui pelatihan ini, keberanian dan ketanggapan mahasiswa terhadap dinamika perubahan lingkungan akan diuji dan selalu diperbaiki dan dikembangkan.

d. Otodidak. Melalui berbagai media mahasiswa dapat menumbuhkan semangat berwirausaha. Misalnya melalui biografi pengusaha sukses (sucess story), media televisi, radio majalah koran dan berbagai media yang dapat diakses untuk menumbuhkembangkan jiwa dan semangat wirausaha. Melalui berbagai media tersebut, ternyata setiap orang dapat mempelajari dan menumbuhkan jiwa wirausaha.

Pertanyaannya, aspek-aspek kejiwaan apa saja yang mencirikan bahwa seseorang dikatakan memiliki jiwa wirausaha? Untuk membahas lebih lanjut mengenai pertanyaan tersebut, penulis 
akan mencoba membahas pendapat Suryana bahwa orang-orang yang memiliki jiwa dan sikap kewirausahaan, yaitu. ${ }^{22}$

a. Percaya diri. Percaya diri artinya yakin, optimis dan penuh komitmen dalam menentukan sesuatu, percaya bahwa kita dapat mengatasi berbagai risiko yang dihadapi merupakan faktor yang mendasar yang harus dimiliki oleh wirausaha. Seseorang yang memiliki jiwa wirausaha merasa yakin bahwa apa-apa yang diperbuatnya akan berhasil walaupun akan menghadapi berbagai rintangan. Tidak selalu dihantui rasa takut akan kegagalan, sehingga membuat dirinya optimis untuk terus maju

b. Inisiatif. Menunggu akan sesuatu yang tidak pasti merupakan sesuatu yang paling dibenci oleh seseorang yang memiliki jiwa wirausaha. Dalam menghadapi dinamisnya kehidupan yang penuh dengan perubahan dan persoalan yang dihadapi, seorang wirausaha akan selalu berusaha mencari jalan keluar. Mereka tidak ingin hidupnya digantungkan pada lingkungan, sehingga akan terus berupaya mencari jalan keluarnya

c. Disiplin, disiplin berarti menempati janji menyangkut waktu, kerja, atau norma, disiplin pada hakikatnya merupakan paksaan, karena ia itu dapat ditegakan melalui cara senang hati, atau memaksakan diri, memaksakan diri bukan berarti dengan nekat atau ngawur, tapi bermakna untuk melakukan kerja atau tugas sesuia rentang waktu yang ditetapkan.

d. Kreatif. Landasan kuatnya jiwa wirausahaan yang berwawasan wiraswasta selain percayadiri, inisiatif, disiplin adalah kreatifitas, kreatifitas adalah kreatifitas yang kuat dan dapat terealisasi bila seseorang itu memiliki daya pikir, gagaan yang kuat, dan perfikir positif sehingga diperoleh karya baru. Karya baru yang dimaksud bisa merupakan imbas, modifikasi atau kombinasi dari karyalama, yang penting ada hal yang baru dan bernilai tambah. ${ }^{23}$

\section{Kesimpulan}

Pendidikan Entrepreneurship merupakan salah satu bentuk aplikasi kepedulian dunia pendidikan terhadap kemajuan bangsanya. Di dalam pendidikan kewirausahaan diperlihatkan di antaranya adalah nilai dan bentuk kerja untuk mencapai kesuksesan. pendidikan kewirausahaan adalah pertolongan untuk

\footnotetext{
${ }^{22}$ Suryana, Kewirausahaan, Pedoman Praktis, Kiat dan Proses MenujuSukses, (Jakarta: Salemba Empat 2003) 21.

${ }^{23}$ Banbang Murdaka Eka, Kewirausahaan, (Yogyakarta: CV andi offfest, 2015), 50.
} 
membelajarkan manusia sehingga mereka memiliki kekuatan pribadi yang dinamis dan kreatif sesuai dengan kepribadian bangsa Indonesia yang berdasarkan pancasila. menumbuhkan jiwa kewirausahaan merupakan salah satu hal yang penting menjadi kesempatan kerja, pendapatan dan kesejahteraan bagi setiap orang/individu.

\section{Daftar Pustaka}

Alma, Buchari. Kewirausahaan, Bandung: Alfabeta, 2016.

Barnawi dan Mohammad Arifin. School Preneurship: Membangkitkan Jiwa dan Sikap Kewirausahaan Siswa, Jogjakarta: Ar-Ruzz Media, 2012.

Eka, Bambang Murdaka. Kewirausahaan, Yogyakarta: CV andi offfest, 2015.

Fadlullah. Pendidikan Enterpreneurship Berbasis Pendidikan Islam dan Kearifan Lokal. Jakarta: Diadid Media Press, 2011.

Hendro. Dasar-Dasar Kewirausahaan. Jakarta: Erlangga, 2011.

Irianto, Yoyon Bahtiar. Kebijakan Pembaharuan Pendidikan: Konsep, Teori, dan Model. Jakarta: PT. Rajagrafindo Persajaq, 2012.

J. Wijardi. Enterpreneur dan Enterpreneurship. Jakarta: Kencana, 2008.

Kasmir, Kewirausahaan. Jakarta: PT Raja Grafindo Persada, 2011.

Mulyani, Endang. Model Pendidikan Kewirausahaan di Pendidikan Dasar dan Menengah. 2014.

Mulyoto, Strategi Pembelajaran di Era Kurikulm 2013. Jakarta: Prestasi Pustaka Raya, 2013.

Rofiq A., R.B. Widodo, dkk., Pemberdayaan Pesantren Menuju Kemandirian dan Profesionalisme Santri dengan Metode Dauroh Kebudayaan. Yogyakarta: Pustaka Pesantren, 2005.

Saputra, Kiki. Pendidikan Berbasis Enterpreneurship, Upaya untuk Mutu Pendidikan Secara Mandiri. Yogyakarta: DIVA Press, 2015.

Suryana, Kewirausahaan, Pedoman Praktis, Kiat dan Proses Menuju Sukses. Jakarta: Salemba Empat, 2003.

Suryana, Yuyus dan Kartib Bayu, Kewirausahaan: Pendekatan Karakteristik Wirausahawan Sukses. Jakarta: Kencana, 2011.

W.S. Wingkle S.J, Psikologi Pengajaran, Yogyakarta: Media Abadi, 2009. 